primates, whereas Hrdy goes deeply into the observed behaviour of females of numerous primate species and makes little reference to evolution as read from the fossil record.

According to Mellen, "love" emerged some three million years ago as an important adhesive force for human social groups and for successful child-rearing. His definition of love slides between conscious emotional attachment and sexual attraction; the large human brain is implicitly involved, but how human love differs from the emotional bonds of higher non-human primates is not always clear His shortest chapter ( 7 pages) is titled "Love Between Parents and Children", the longest (46 pages), "The Enigma of Homosexual Love", by which he means male homosexual love.

Mellen's book belongs with the 1960s genre in that the framework is Man-the Hunter and male choice of females. A central issue is male access to females, in order to be assured of their procreative potential, sexual receptiveness and "love". Hunting is credited with our acquisition of intelligence, cooperation, communication and food-sharing (old stuff); and (a new twist) men had many mates and natural selection enhanced "capacities for suspending fear" which resulted in the surviving hunters passing on "their courageous genes ... to many sons". Sociobiological theory tends to find a gene for every behaviour, and so Mellen explains that "finally the world came to be rather full of men whose chromosomes carried certain invidious genes for preferring young women', surely an unnecessary exegesis in a world in which, until very recently, few females or males lived beyond the age of 30 or 40 .

The Woman That Never Evolved challenges some of the sexual stereotypes that Mellen perpetuates, almost to the point of reversing them. Hrdy argues that the ubiquitous domination of females by males is a product of primate evolutionary history, as male domination is the rule (with few exceptions) among non-human primates. She brings together a broad array of up-to-date information on females of many species, from galagos to gelada baboons. Of particular interest are the chapters on monogamous primates, among which females enjoy relatively privileged positions, and on those species such as lemurs and squirrel monkeys in which there is no clear dominance of males over females.

Hrdy lays the greatest emphasis on female competition and status-seeking, as though to prove that women have inherited all the same undesirable traits that men possess and therefore should be equally successful. She states that "competition among females is central to primate social organization", and that "every female is essentially a competitive strategizing creature". Obviously, all members of a group "compete" to some extent for food, status and sexual partners, but, as in an atomic nucleus, the disruptive forces must be less than the cohesive ones if the group is to survive. In most species, male access to females is more limited than female access to males, hence male-male competition would be expected to be, and is observed to be, more intense than competition among females.

Hrdy's evolutionary construct is reminiscent of those of the 1960s, with a sort of reversal of roles. It is females rather than males who are competitive and statusseeking, but instead of forming clubs and political parties, they use their sexuality to gain power and domesticate males and keep them from killing their infants. Hrdy's observation that "outside" male langurs will sometimes take over a troop and kill the offspring of lactating mothers - presumably so that they can reimpregnate these females with their own genes - is raised to the level of a paradigm: by the iron laws of sociobiology, primate males will try to "murder" offspring not their own and must be prevented from doing so by female strategems.

The woman that never evolved, according to Hrdy, is the woman invented by contemporary feminists: "created equal", having a natural sense of solidarity with other women and innocent of the male lust for power and status. Hrdy seems to assume that culture plays no role in the behaviour of women, and if certain kinds of behaviour are not found in other primates, they will not be found in humans.

I have improvised a dialogue between Mellen and Hrdy, to contrast their concerns and conclusions. Mellen: "Protohuman females were evolving in the direction of ever-increasing care and nurture of the young". Hrdy: "The vision of assertive, dominance-oriented females differs radically from existing stereotypes of female primates as non-stop mothers whose perennial preoccupation with nurturing offspring keeps them out of politics". Mellen doubts that pleasure from sexual intercourse is common for women. Hrdy retorts that female sexual activity is "assertive and temporarily insatiable".

Both of these books join the growing stacks of sociobiological attempts to integrate genes and human behaviour. They fail by ignoring the intervening levels that influence the outcome of behaviour development, socialization, symbols, ritual and values that are passed on nongenetically from generation to generation. Instead, they invoke hypothetical genes evolved either by hypothetical Pleistocene screenplays or deduced from selected observations on non-human primates and contemporary cultures. Mellen and Hrdy draw nearly opposite conclusions from their gene-based reconstructions. The book that has not yet been written is one that recognizes several levels of analysis, that integrates culture and biology and that interprets female and male behaviour in a mutually adaptive social system.

Adrienne L. Zihlman is a Professor of Anthropology at the University of California, Santa Cruz.

\title{
Taste for travel and a naturalist's eye
}

\section{A.J. Cain}

The Roving Naturalist: Travel Letters of Theodosius Dobzhansky. Edited by Bentley Glass. Pp.327. ISBN 0-87169-1396. (American Philosophical Society, Philadelphia: 1980.) $\$ 8$.

THEodosius Dobzhansky was a truly remarkable man, of great personal experience, shrewdness, humanity and intellectual ability. He wrote clear, vigorous, masculine prose, expressing the forceful thoughts of a first-class observer. This book of his letters and reminiscences is a delight; one can dip into it anywhere and find oneself in grand company. Even when his reactions are the usual ones - to the grandeur of tropical forests, the horrors of temperate-zone poverty or "lousy bureaucracy" - he expresses them with a freshness that always precludes banality. The book would be excellent at one's bedside for those with strength enough to ration themselves to a single letter.

There is an excellent, short biographical introduction by Bentley Glass which gives the major events in Dobzhansky's extraordinarily varied and interesting lifehistory. He was born in the Ukraine in 1900 . In 1910 the family moved to Kiev. The boy, already a keen butterfly collector, went on a school excursion to the Caucasus; two years later he and a friend went off by themselves without parental permission to that fascinating region. His tastes for travel and entomology were already developed.

As a student at Kiev University, supporting his widowed mother, he had a difficult time towards the end of the Great War, and during the Revolution, in 1919, they experienced the Communist terror. Typhus, the invasion of the Polish Army, the death of his mother and severe privations in the winter of 1919-1920 were serious afflictions which he survived, becoming a private tutor, a graduate, an assistant to one of the professors of zoology and a tutor in the Workers' 
Faculty. Soon after, he visited Moscow to see the genetical researches of Chetverikov and his group, who had stocks of Drosophila given to them by H.J. Muller. Then he migrated to Leningrad, and was sent on scientific expeditions to Central Asia to study genetic variation in domestic animals - he seems to have studied nearly every other biological phenomenon as well, especially human beings. The first part of this book is his enthralling reminiscences of his travels in Central Asia between 1925 and 1927 . In 1927 he and his wife went to the USA to work with Thomas Hunt Morgan at Columbia University, and he began that illustrious career in population genetics using Drosophila.

The problems arising from his investigations into populations of Drosophila in the USA demanded wider genetical explorations. The letters in the book (unfortunately we are never told to whom they were written, which would often clarify their mode of treatment of some topics) were written on his visits to Brazil (1948-1953), to other countries of South America (1955-1958), to Israel, Lebanon and Egypt (1956) and India, Indonesia and New Guinea (1960). He must have been a superb correspondent. As is to be expected, since the reminiscences were taped later in his life and the first letter dates from 1948, his character, after the sometimes hair-raising experiences of his youth, was fully formed. Thus we see no development of character in the book any more than there is in, for example, the short stories of "Saki", but the absence of that is more than compensated for by being able to see through the eyes of so good an observer and writer such a variety of landscapes, organisms, people and situations, sometimes hilarious, often exasperating, but always exciting.

He had a naturalist's eye for animals, plants and people, and excellent appreciation of landscape (less so for geology), a sharpness for human (as well as animal) character, and a lovely dry humour, very like "'Saki's", all of which come out just as well in his letters as they did in his conversation. No empty pomposity ever imposed on him, and not many other involuntary psychological deceptions. The freshness of his response to tropical nature seems at first naive (but never boring, gushing or silly) because it is so immediate, but naive he was not. $\mathrm{He}$ turned a sharp eye inwards on himself as well - there are some extremely interesting obiter dicta on his own reactions to mountains, uninhabited tropical islands, palms, the tropical night and the Holy Land.

Dedicated drosophilists must be warned that there is little in the book about Drosophila. Everyone else will find a lot in it.

A.J. Cain is Derby Professor of Zoology at the University of Liverpool.

\section{Missing the essential Professor Eysenck}

\section{P.E. Bryant}

Hans Eysenck: The Man and His Work. By H.B. Gibson. Pp.275. ISBN 0-7206-0566-0. (Peter Owen, London/Humanities Press, New Jersey: 1981.) £11.95, \$26.

THE mainspring of the considerable body of research carried out by Professor Eysenck and his colleagues has always been his theory of personality. This is based on two ideas: the first is that everyone's personality can be described in terms of the person's position along three separate dimensions, and the second that the mechanisms which underlie these dimensions are, in principle, discoverable.

None of the specific details of his account of personality - the use of factor analysis, the three dimensions of introversion-extraversion, neuroticism and psychoticism or the use of the notions of excitation and inhibition and, later, of arousal to explain these dimensions - was in itself particularly new, but it has led to a great deal of original and fruitful research and it has also propelled Eysenck into a series of major controversies.

Anyone who has spent half-an-hour or more with one of his many books will know something of the theory and will also have learned that Eysenck not only revels in these controversies but also writes about them vividly and lucidly. Such characteristics are a distinct advantage in a psychologist. Controversy is the life-blood of psychology. The subject is still finding its feet, and this means that nothing much is certain and nothing can be taken for granted. Every single claim has to be argued over.

No one has recognized this or demonstrated it more than Eysenck. He is nettled, and often quite rightly, by anything that looks like a respectable consensus. It has been the established academic view that individual differences are rather unimportant in psychology, that people with extreme left-wing views are very different in personality from people on the extreme right, that psychoanalysis works, that a person's intellectual abilities are largely determined by the environment in which he grew up, that astrology is bunk and that smoking is a cause of cancer. Eysenck has at various times disagreed quite violently with all these respectable sentiments, and whether or not his objections are right they are always argued cogently.

His relish for battle and the clarity with which he presents his blow by blow accounts of them to psychologists and laymen alike represent an important contribution to psychology, but there is much more besides. He, more than anyone, shaped the development of clinical psychology in this country. He, too, fought valiantly and successfully against the unfortunate tendency among psychologists to break up into quite separate camps which do not talk to each other and which pursue different questions with quite different methods. Eysenck insisted that the question of personality was too important to be left just to the personality testers. The methods of experimental psychology, he argued, were also needed to explain why people are different from each other. $\mathrm{He}$ managed to build a bridge between the two camps which has lasted extraordinarily well, so that nowadays no one using personality questionnaires can afford to

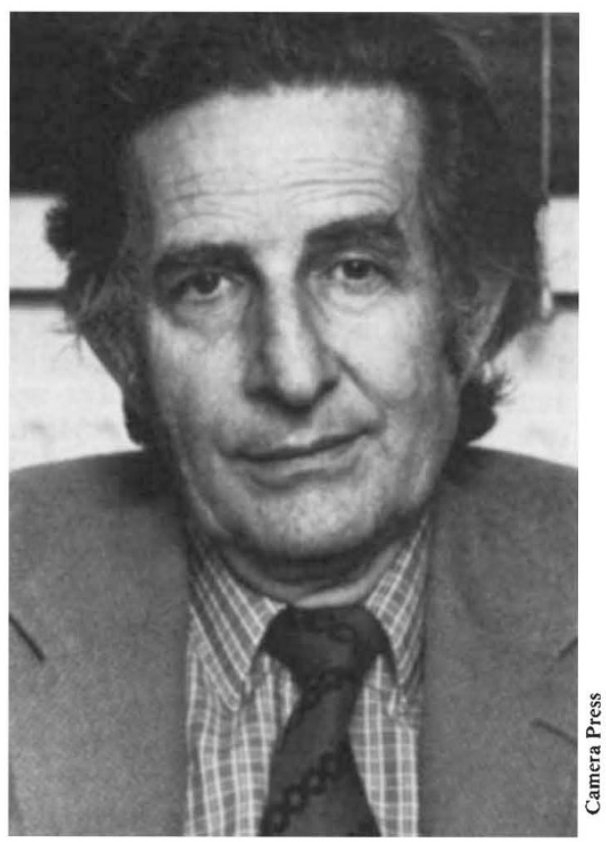

Hans Eysenck - "nettled . . by anything that looks like a respectable consensus".

ignore laboratory research just as no one doing laboratory experiments can resort to the easy assumption that what is true about the behaviour of one person is true as well of everybody else. This link between two hitherto separate disciplines is in my view Eysenck's greatest achievement.

Such a man obviously deserves the accolade of a biography, and H.B. Gibson's account of Eysenck's life coming out as it does near to his retirement ought to give us a good idea not only of Eysenck's own development but also of his considerable influence on psychology over the last three decades. But it does not. Gibson's book is at its strongest when it recounts the simple facts about Eysenck's life - his early upbringing in the Weimar Republic and then under the Nazi regime, his revulsion against the Fascist system and his consequent move to England, his decision faute de mieux to study psychology (mieux in this case being physics), his early work with Burt and then his subsequent move under the tutelage of Aubrey Lewis to the Institute of Psychiatry in order to set up the clinical psychology department there.

But we need to know more than that and 